Wirtschaftswissenschaftliches Zentrum (WWZ) der Universität Basel

$\mathrm{WW} \mid \mathrm{Z}$

January 2012

\title{
Foundations of Corporate Governance
}


The Author:

Dr. Christophe Volonté, Assistant

Faculty of Business and Economics

University of Basel

Peter Merian-Weg 6

$\mathrm{CH}$ - 4002 Basel

phone: +41(0)612672462

christophe.volonte@unibas.ch

A publication of the Center of Business and Economics (WWZ), University of Basel.

(c) The author. Reproduction for other purposes than the personal use needs the permission of the author. 


\title{
Foundations of Corporate Governance*
}

\author{
Christophe Volonté ${ }^{\dagger}$ \\ University of Basel \\ Faculty of Business and Economics \\ February 2, 2012
}

\begin{abstract}
This paper outlines the foundations of corporate governance. The discussion includes a review on the modern corporation, transaction costs theory, agency costs theory, legal investor protection, investor protection by corporate governance and its various mechanisms, as well as an overview of the determinants of corporate governance.
\end{abstract}

JEL-Classification: G30; G32; G34; K00

Keywords: Agency theory; Legal protection; Corporate governance; Board of directors; Ownership

*This publication is based on chapter 2 of my PhD thesis "Corporate Governance in Switzerland", University of Basel, 2011.

${ }^{\dagger}$ Christophe Volonté is assistant at the Henri B. Meier Department of Financial Management, University of Basel, Switzerland. Address: Faculty of Business and Economics, Peter Merian-Weg 6, CH-4002 Basel, Switzerland, Tel: +41-61-267-24-62; fax: +41-61-267-24-63; e-mail: christophe.volonte@unibas.ch. 
The Industrial Revolution of the 19th century with its technological advances and its increasingly capital-intensive (mass) production processes increased the optimal size of many firms (see Jensen, 1993). Their greater production capacity made them difficult to be financed by a single person. In consequence, former sole proprietorships were being replaced by large public corporations with limited liability along with somewhat dispersed ownership (Holderness, 2003). Ownership and control were separated and, as a result, the foundations of economic activity changed. The owner and the manager were no longer one and the same person. ${ }^{1}$

A firm's capital requirements can be met in the form of debt or equity, respectively in a combination of the two. Providers of debt receive a pre-fixed and stable return of cash flows. Additionally, debtholders can claim collateral in the case of payment default, and they can adjust the contract if pre-specified covenants are breached. Hence, debtholders are exposed to relatively low risk, however, with naturally limited return potential.

In contrast, providers of equity are only apt to invest their wealth in risky firms if they can be sure of receiving a return once all expenses including the managers' compensation have been paid. Shareholders are only entitled to the residual claim on the earnings. Hence, there is a potential conflict of interest between shareholders and managers. As a consequence, equity-investors depend on the credibility of managers, corporate governance, and a well-functioning legal system that prevents any of the owners' capital being expropriated by the managers who are in control of it.

\section{Excursus: The Ownership of the Modern Corporation}

U.S. corporations are characterized as being held by dispersed shareholders with only small interest in the corporation. This situation accentuates the problem of selfinterested managers mentioned earlier, a phenomenon which is observed all over the world and not only in the United States. Nevertheless, the extent of problems between managers and shareholders depends on the ownership structure of the firm and the identity of the shareholders (see Bogle, 2005). Variations in the ownership structure are observed over the time, but also across firms and countries.

On the one hand, some listed firms and most non-listed firms, are held by strong shareholders with significant voting rights. These "controlling" shareholders often take an active part in the firm's business (owner-capitalism). As a result, ownership and control partly overlap and conflicts of interest decrease.

On the other hand, some firms are held by dispersed and passive shareholders. The managers of these firms are hardly monitored and, as a result, they try to run

\footnotetext{
${ }^{1}$ See Cooter and Ulen (2008) for a discussion of different financing sources depending on the firm's stage of development and the quality of the institutional framework within a country.
} 
the company for their own private benefits and to consolidate their position (managercapitalism). Frequently, such firms grow beyond their optimal size and diversify into different business segments.

However, badly managed firms can become subject to shareholder interventions. For instance, some institutional investors intervene successfully to change a firm's structure. Other firms disappear completely once taken over by or merged with another firm. Waves of mergers and acquisitions have been observed since the inception of the modern corporations. For instance, the merger wave in 1890 transformed relatively small corporations into larger entities (see Jensen, 1993). More recently, so-called alternative investors such as private equity funds have continued to restructure corporations, often by leveraged buy-outs focusing on core competencies and changing corporate governance (Jensen, 1993).

Other countries determine their individual ownership specifications, which, in turn, entail other respective agency problems. For instance, in Germany, banks tend to play an important role ("Hausbankensystem"). In France, firms are affected by interventions of the state. And in other continental European countries and in Asia, firms are typically held by large industrial groups or family clans (Kraakman et al., 2009).

\section{Transaction Cost Theory}

Modern corporations have relatively easy access to finance; however, their shareholders are heavily reliant on the managers. Two related questions arise: why do people create firms if they trigger such problems? And why do they not trade their products and services on markets? Coase (1937) argued that the integration of trade within a firm takes place if the transaction costs using the market are higher than the costs using an internal organization. The reason is that, in contrast to neoclassical assumptions, using the market is not free of costs. In the real world, there are no frictionless markets (see Allen et al., 2009). These transaction costs include the costs of information, search, negotiation and re-negotiation, contracting, and enforcement (see Williamson, 1985). Transaction costs exacerbate the problems associated with setting a complex bilateral, long-term, and complete contract. Complete contracts would contain all information about the future and instructions for every possible state of the world. ${ }^{2}$ In conclusion, if complete

\footnotetext{
${ }^{2}$ In the context of contracts, frequently one of the parties has an information advantage. The problem of asymmetric information emerges before and after a contract has been written. Ex-ante, the qualities of the parties involved; i.e., their characteristics and intentions, are often unobservable (Arrow, 1984). There is a risk of an adverse selection; i.e., the risk of choosing a bad counterparty. The second problem of asymmetric information occurs after the completion of the contract. Ex-post, moral hazard can be an issue. The contracting parties may not behave as expected, and the (hidden) action cannot be observed.
} 
contracts were feasible, all transactions would take place on markets and not within a corporate hierarchy.

\section{Agency Cost Theory}

Corporations accomplish an important task and fulfill incomplete contracts at the lowest costs. However, again, a complete contract between managers and shareholders is not feasible. As a result, there is leeway that might be exploited by the managers, and, in consequence, shareholders might be harmed.

As early as 1776, the famous Scottish economist Adam Smith described this problem as a conflict that occurs when someone controls resources that he does not own personally. However, contrary to his misgivings "joint-stock companies" did successfully survive (see Allen et al., 2009). In 1932, Berle and Means addressed this concern and related it expressly to modern corporations with their typical separation of ownership from control. Finally, in 1976, Jensen and Meckling termed this conflict of interest between shareholders and managers the principal-agent problem, regarding it as the cause of so-called agency costs. The problem occurs if a principal employs an agent to act on his behalf, the two parties being both rational and self-interested. Most commonly and in respect to corporations, the principal-agent problem describes the problem between managers (agents) and shareholders (principals). However, agency relationships occur in many other situations. ${ }^{3}$

Agency costs accrue when managers do not behave in the way the suppliers of finance desire. Shareholders expect the managers to use their resources in a productive way. They should invest the money in positive net present value projects that increase firm value and, thereby, the residual claim for shareholders. In contrast, if there are no profitable investment opportunities, money should be returned to shareholders. However, reality is not always as idealistic as this, and the interests of principals and agents are not always aligned. Generally speaking, self-interested managers may pursue shareholder value-reducing activities, increase their personal benefits, and thereby find themselves unable to provide the risk-adjusted return that the shareholders expect to receive.

Shareholders have difficulties evaluating the actions of the managers, because the asymmetric distribution of information causes managers to profit from an informational advantage. Managers typically have more information about the firms' situation and its

\footnotetext{
${ }^{3}$ Basically, such costs arise whenever a principal delegates work to an agent (e.g., a patient-physician relationship). In addition, within a corporation various conflicts of interest can occur. They can involve managers and directors, shareholders and directors, different groups of shareholders (see Shleifer and Vishny, 1997) or debtholders and equityholders (see Myers, 1977). The underinvestment and overinvestment theories both deal with the conflict between debt- and shareholders. Furthermore, corporate restructuring or the decision on how to finance or invest is regularly related to the question of whether the rationale solves an old agency problem or creates a new one.
} 
daily business than investors do. This information advantage allows them to undertake discretionary spending. Furthermore, shareholders often do not close the asymmetry, because the acquisition of information and their monitoring efforts are costly. In addition, the efforts would be shared with free-riding fellow shareholders. In such circumstances, monitoring would assume the form of a public good, and the effort thus produced would be sub-optimal.

These conflicts of interest intensify, because financial incentives between shareholders and managers typically differ substantially. In contrast to shareholders, managers remunerated by fixed compensation do not participate in the gains when the firm's value increases. However, they can invest the shareholders' money in activities that augment their private benefits. Hence, the problem becomes more aggravated, the less financially committed the manager is to the firm (see Jensen and Meckling, 1976). In addition, managers are usually more risk-averse than shareholders, which further misaligns the interests. While shareholders can diversify their financial risk over different investments, professional managers are typically specialized in their field of work and risk their job if projects fail (see Eisenhardt, 1989).

Managerial activities that reduce the profits available for shareholders are manifold, some more obvious than others (see Shleifer and Vishny, 1997). Managers can expropriate money, for instance, by selling firm assets to their own companies at lower prices. Other private benefits include the consumption of perquisites. This includes expensively furnished modern offices, fancy company cars, luxurious corporate trips or company jets. Furthermore, managers may try to expand their firm's size, pursue "pet projects", and create an "empire" that increases their claim for remuneration that is often linked to sales, and makes them more difficult to being dismissed since their personal contribution is less easy to assess (see Jensen, 1986; Shleifer and Vishny, 1989).

\section{Legal Protection}

There is basic legal protection against managerial misbehavior that applies in any economic activity. Notably, duty of care and duty of loyalty restrict a manager's capability to expropriate shareholders. The legal framework within a country defines the scope and terms of its corporate governance rulings. Empirical evidence shows that the level of investor protection is related to the level of equity investments and corporate governance (La Porta et al., 2002). Countries with insufficient legal enforcement are seen to be associated with a lower quality of corporate governance and are observed to have difficulty in attracting external capital (Shleifer and Vishny, 1997). Furthermore, other legal mechanisms such as disclosure practices or transparency requirements help investors to reduce information asymmetry. The legal framework sets strict rules of investor protec- 
tion and indirectly influences the configuration of corporate governance at firm level (see Easterbrook and Fischel, 1989).

\section{Corporate Governance}

Corporate governance can be defined as a set of (mostly voluntary) devices that aim to protect investors against managerial misbehavior. "Good" corporate governance is believed to reduce the likelihood of bad or wrong management and, as a result, to create shareholder value. However, its form and implementation are largely left to the discretion of the firms. Corporate governance is set up in two steps.

In the first step, the founders decide on the firm's form of incorporation. The corporate form is written down in the articles of incorporation and the bylaws (see Kraakman et al., 2009). Thereby, the founders record the firm's basic governance principles and define the desired investor base. For instance, the specification of the capital structure can favor some investors over other; e.g., by means of a dual-class share structure.

In the second step, the shareholders - who are free to invest or not - may change the firm's governance after the firm has been established and the capital has been raised. This can be done through voting at general meetings or more directly, by electing convenient directors on the board.

Furthermore, corporate governance can be separated into mechanisms that are firminternal or firm-external. The most important corporate governance devices include the board of directors, the shareholders, the market for corporate control, the capital structure, executive compensation, and, not least, competition at various firm levels.

\subsection{Internal Governance Mechanisms}

\section{- Board of directors}

The board of directors is elected by the shareholders at the general meeting and represents their interests. Consequently, its most important task is to monitor management on the shareholders' behalf. ${ }^{4}$ This implies that its primary responsibility, upon which its legitimacy rests, is to reduce agency costs. As such, the directors' responsibility is to fire bad managers and to reject unprofitable long-term investments. ${ }^{5}$ For this reason, the composition and structure of the board is an important topic in corporate governance.

Crucial factors at board level include the independence of the board vis-à-vis the management, including CEO duality, and the commitment of directors outside the board

\footnotetext{
${ }^{4}$ In this thesis, the board is mainly viewed from an agency perspective. However, some alternative theories explain the board and its function, as well. Examples include the stewardship theory (Donaldson and Davis, 1991; Davis et al., 1997), resource dependence theory (Pfeffer and Salancik, 1978), and management entrenchment theory (Shleifer and Vishny, 1989).

${ }^{5}$ Kind and Schläpfer (2011) show that stock markets react negatively to the dismissal of good CEOs.
} 
room. Furthermore, board composition is important, e.g., the professional and personal profiles of its directors. However, in the past, directors have often been blamed for not protecting shareholder interests, for colluding with management, and for being too passive in general. ${ }^{6}$

\section{Excursus: Comparison of Boards in an International Context}

Boards are broadly classified into one-tier (unitary or monistic) boards and two-tier boards. In a system of one-tier boards, all responsibility is delegated to one corporate body. Hence, this form of board typically consists of executive and non-executive directors. In this case, the executive directors both manage and supervise daily business. In contrast, two-tier boards have a supervisory board that is separated from the management board and which consists solely of non-executive directors. In practice, two-tier boards are prevalent in most of Continental Europe even though one-tier boards are legally allowed.

- Boards in the United States and the United Kingdom are one-tiered. The structure allows executives to hold positions on the board, sometimes led by a CEO who is also chairman of the board at the same time. However, in most cases, an executive management is in charge of daily business. Directors are elected by shareholders at the annual general meeting.

In the United States, 54 percent of all boards have a combined leadership structure (RiskMetrics Groups, 2008). In contrast, the chairman and CEO positions are usually separated in the United Kingdom. Only 16 percent of U.K. firms exhibit CEO duality (see Weir et al., 2002).

In Switzerland, the board of directors is legally an executive body. However, typically, the board of directors ("Verwaltungsrat") is the supervising organ, while operating activities are delegated to a management board ("Geschäftsleitung" or "Konzernleitung"). The general meeting ("Generalversammlung") elects the board of Swiss firms.

- Two-tier boards have a supervisory board that is strictly separated from the management board. In consequence, the supervisory board is composed solely of nonexecutive directors.

In Germany, the dual board system consists of a management board ("Vorstand") and a supervisory board ("Aufsichtsrat"). The supervisory board consists of solely

\footnotetext{
${ }^{6}$ However, corporate governance devices such as the board of directors are present in other organizational forms that have no explicit financial objectives (e.g., universities or NGOs.)
} 
non-executive directors and is elected by the general meeting ("Hauptversammlung"). In addition, a percentage must be employee representatives.

In France, both types are common. One-tier boards are denominated "conseils d'administration". Such firms are usually guided by the président-directeurgénérale (PDG). He represents the board operatively as their delegate ("delegué") on the management board and is usually the CEO ("directeur générale") and chairman ("président du conseil d'administration") in one person. In contrast, two-tier boards consist of the supervisory board ("conseil de surveillance") and the management board ("directoire") similar to German boards. The general meeting ("assemblée générale") elects the directors.

\section{- Shareholders}

Shareholders do, at least partially, monitor the management themselves. They have the right to vote on important corporate decisions, especially on who is appointed to the board of directors. However, the ownership of firms is commonly too fragmented for shareholders to be motivated to take action on issues. Because of free-riding co-owners, individual investors are rather passive. In contrast, large shareholders, so-called blockholders or controlling shareholders, usually have an incentive to actively monitor management. However, as the controlling shareholders gain influence, other conflicts might emerge. The interests of controlling shareholders and minority shareholders might collide. Controlling shareholders might only act on issues that are beneficial for them. In this case, a trade-off evolves between weak and excessively powerful shareholders.

\section{- Executive compensation}

In contrast to the two monitoring devices mentioned before, executive compensation can be used to incentivize the management. Variable compensation ("pay-for-performance") can align the interests of both the management and the shareholders (Jensen and Meckling, 1976). However, one important condition for this mechanism to work properly is the fact that the manager's performance and quality is reflected in the market price, and this requires an efficient capital market. In fact, executive compensation nowadays is rather seen as a agency problem than a governance device. Overly powerful corporate managers are empowered to dictate the level and the configuration of the salary to a seemingly helpless board. 


\subsection{External Governance Mechanisms}

\section{- Market for corporate control and takeover defenses}

The market for corporate control, including the fear of hostile takeovers, can also discipline the management (Manne, 1965; Jensen and Ruback, 1983). This mechanism is particularly important in Anglo-Saxon countries where the ownership of the firms is commonly dispersed and the capital markets efficient. If stock prices reflect the ability of the management, poor managerial decisions lead to falling prices and, thereby, increase the probability of the firm becoming a takeover target. Thus, managers adopt actions that sustain firm value.

However, the board can also install takeover defenses to mitigate this mechanism. Takeover defenses differ substantially across countries and firms, but their objective is always the same. They decrease the probability of a hostile takeover, which has the consequence of entrenching the management.

\section{- Capital structure}

The configuration of the capital structure can also be a means for disciplining the management. High debt and pre-determined interest payments, in contrast to the residual claims by shareholders, put pressure on the management and make them economize resources. In short, interest payments reduce the free cash available for investments in negative net present value projects (see Jensen, 1986). Furthermore, the credit ratings of debt-issuing firms can reduce information asymmetry between managers and debtholders. However, conflicts of interest between debt- and shareholders can arise (see Myers, 1977).

\section{- Competition}

Competition is a natural mechanism that prevents wasting money and acts on three main markets. Firstly, as discussed before, the market for corporate control exposes badly run companies to the danger of a hostile takeover. Secondly, the managerial labor market allows managers to signal their ability in order to increase their market value and prestige (see Fama, 1980). Thirdly, competition in the product market leads to an economization of resources in order to remain competitive and in the market (see Beiner et al., 2009).

\section{Determinants of Corporate Governance}

Effective corporate governance has to be adequately structured in line with the firm's environment. The firm's environment includes three broad areas. Firstly, the legal frame- 
work sets the scope of governance exogenously. This can be understood as the under and upper bounds of discretionary leeway in creating firm-specific governance. Secondly, the corporate governance pattern can actively influence the relative strength of various institutions within a firm (e.g., share- or debtholders). Thirdly, the operational environment determines the requirements of an optimal corporate governance structure (e.g., depending on the industrial affiliation).

\subsection{Legal Environment}

A firm's legal environment is defined primarily by the written legislation and the law enforcement by the state. In Switzerland, the Code of Obligations (SCO) of 1911 includes contract law, company law, and securities law and specifies the firm's leeway in structuring corporate governance. In addition, listed corporations have to comply with the Stock Exchange Act (SESTA) of 1995. Furthermore, some industries such as the banking industry are subject to specific regulations.

Moreover, the SIX Exchange Listing Rules set reporting requirements for financial transparency and corporate governance, among other things. Economiesuisse, an organization of the Swiss economy, has also published guidelines for best practice in corporate governance called "Swiss Code of Best Practice for Corporate Governance" (see Economiesuisse, 2008).

Finally, companies cross-listed outside of Switzerland are affected by foreign corporate governance codes and legislation. As the case may be, cross-listed firms in the United States have to comply with the Sarbanes-Oxley Act of 2002 and New York Stock Exchange listing rules.

\subsection{Corporate Governance Environment}

The general corporate governance environment (or primarily the corporate ownership structure) determines some of the agency problems occurring in a firm. Shareholders can influence corporate governance as they can elect the directors and vote for a change in the firm's articles of incorporation. Strong investors can mitigate the problems between managers and shareholders, but they can equally instigate issues between themselves and other investors.

In addition, takeover defenses implemented by boards hamper shareholder action and insulate them from the hazards presented by the market for corporate control. Hence, the general corporate governance of a firm influences the relative importance of other corporate governance devices. 


\subsection{Operational Environment}

The operational or economic environment specifies the firm's requirements set for corporate governance. Corporate governance should be adapted to the firm's needs. Small and fast-growing companies in specific industries may have other corporate governance requirements than those suited to large, mature, and diversified firms. As an example, Lehn et al. (2009) find evidence that boards adapt their structure endogenously to their operational circumstances (e.g., firm size, industry affiliation, and complexity).

\section{Conclusions}

Complete contracts are not feasible, because the transaction costs impede contracts that specify instructions in each state of the world. As a result, firms are established that reduce the transaction costs accrued using the market. The capital-intensive, modern firms that emerged after the Industrial Revolution faced a radical rise in their need for financial funding. The finance was provided - among others - by many small equity investors. In contrast to sole proprietors, those shareholders yielded the control of their resources to managers. The resulting separation of ownership from control led to socalled agency problems. The problem is that managers do not necessarily always act in the interest of the firm's shareholders, which would entail maximizing firm value. The aim of corporate governance is to protect investors against managerial misbehavior. Effective corporate governance is therefore an essential factor in determining a firm's success, and to ensure this, its structure must be aligned to the firm's environment.

\section{References}

Allen, W. T., R. H. Kraakman, and G. Subramanian, Commentaries and Cases on the Law of Business Organization, 3rd. ed., New York: Aspen Publishers, 2009.

Arrow, K. J., "The Economics of Agency," in J. W. Pratt and R. Zeckhauser, eds., Principals and Agents: The Structure of Business, Cambridge: Harvard Business School Press, 1984.

Beiner, S., M. M. Schmid, and G. Wanzenried, "Product Market Competition, Managerial Incentives and Firm Valuation," European Financial Management, 2009, 17 (2), 331-366.

Berle, A. and G. Means, The Modern Corporation and Private Property, New York: McMillian, 1932. 
Bogle, J. C., The Battle for the Soul of Capitalism, New Haven: Yale University Press, 2005.

Coase, R. H., "The Nature of the Firm," Economica, 1937, 4 (16), 386-405.

Cooter, R. D. and T. Ulen, Law and Economics, 5th ed., New York: Addison Wesley, 2008.

Davis, J. H., F. D. Schoorman, and L. Donaldson, "Toward a Stewardship Theory of Management," The Academy of Management Review, 1997, 22 (1), 20-47.

Donaldson, L. and J. H. Davis, "Stewardship Theory or Agency Theory: CEO Governance and Shareholder Returns," Australian Journal of Management, 1991, 16 (1), 49-65.

Easterbrook, F. H. and D. R. Fischel, "The Corporate Contract," Columbia Law Review, 1989, 89, 1416.

Economiesuisse, "Swiss Code of Best Practice for Corporate Governance," Swiss Business Federation, 2008.

Eisenhardt, K. M., "Agency Theory: An Assessment and Review," Academy of Management Review, 1989, 14 (1), 57-74.

Fama, E. F., "Agency Problems and the Theory of the Firm," The Journal of Political Economy, 1980, 88 (2), 288-307.

Holderness, C. G., "A Survey of Blockholders and Corporate Control," Economic Policy Review, 2003, 9 (1), 51-64.

Jensen, M. C., "Agency Cost Of Free Cash Flow, Corporate Finance, and Takeovers," American Economic Review, 1986, 76 (2), 323-329.

_ , "The Modern Industrial Revolution, Exit, and the Failure of Internal Control Systems," The Journal of Finance, 1993, 48 (3), 831-880.

- and R. S. Ruback, "The Market for Corporate Control: The Scientific Evidence," Journal of Financial Economics, 1983, 11 (1-4), 5-50.

- and W. H. Meckling, "Theory of the Firm: Managerial Behavior, Agency Costs and Ownership Structure," Journal of Financial Economics, 1976, 3 (4), 305-360.

Kind, A. and Y. Schläpfer, "Are Forced CEO Turnovers Good or Bad News?," Working Paper, Faculty of Business and Economics, University of Basel, 2011. 
Kraakman, R. H., J. Armour, P. Davies, L. Enriques, H. Hansmann, G. Hertig, K. Hopt, H. Kanda, and E. Rock, The Anatomy of Corporate Law: A Comparative and Functional Approach, 2nd ed., Oxford: Oxford University Press, 2009.

La Porta, R., F. Lopez de Silanes, A. Shleifer, and R. Vishny, "Investor Protection and Corporate Valuation," The Journal of Finance, 2002, 57 (3), 1147-1170.

Lehn, K. M., S. Patro, and M. Zhao, "Determinants of the Size and Composition of US Corporate Boards: 1935-2000,” Financial Management, 2009, 38 (4), 747-780.

Manne, H. G., "Mergers and the Market for Corporate Control," The Journal of Political Economy, 1965, 73 (2), 110-120.

Myers, S. C., "Determinants of Corporate Borrowing," Journal of Financial Economics, 1977, 5 (2), 147-175.

Pfeffer, J. and G. R. Salancik, The External Control of Organizations, New York: Harper and Row, 1978.

RiskMetrics Groups, “Board Practices: Trends in Board Structure at S\&P 1'500 Companies," 2008.

Shleifer, A. and R. W. Vishny, "Management Entrenchment: The Case of ManagerSpecific Investments,” Journal of Financial Economics, 1989, 25 (1), 123-139.

_ and _ , "A Survey of Corporate Governance," Journal of Finance, 1997, 52 (2), 737784 .

Weir, C., D. Laing, and P. J. McKnight, "Internal and External Governance Mechanisms: Their Impact on the Performance of Large UK Public Companies," Journal of Business Finance and Accounting, 2002, 29 (5-6), 579-611.

Williamson, O. E., "Assessing Contract," Journal of Law, Economics, and Organization, 1985, 1 (1), 177-208. 